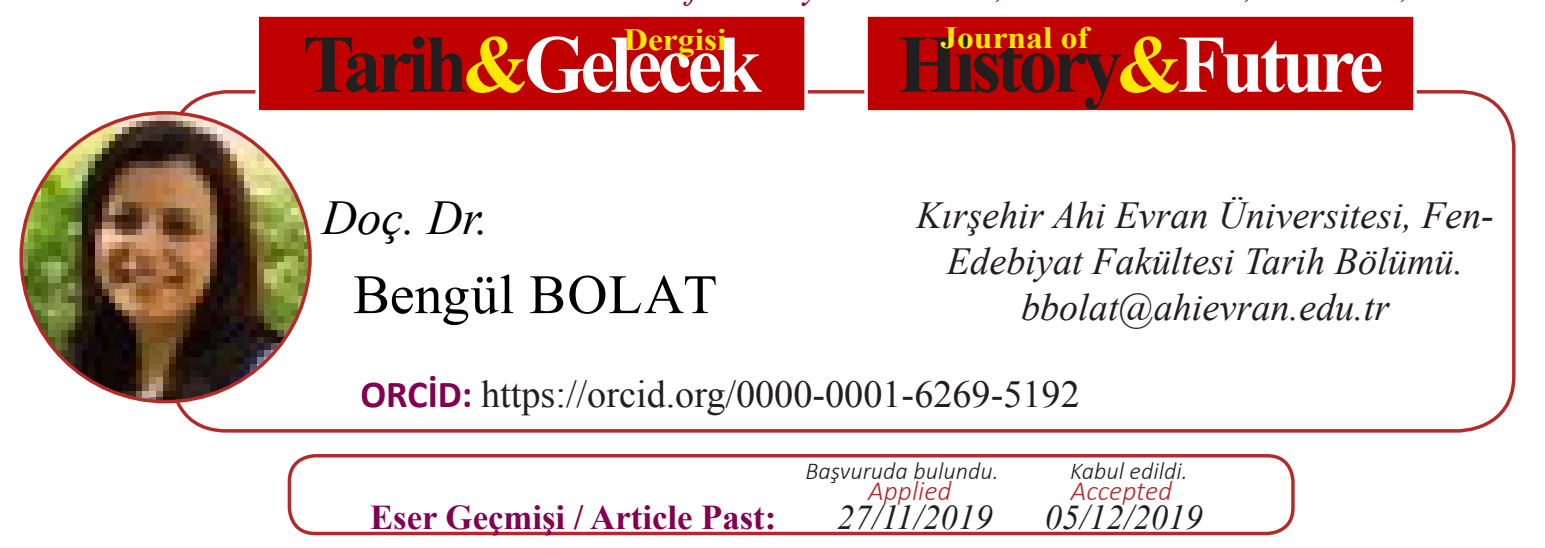

Araştırma Makalesi

DOI: http://dx.doi.org/10.21551/jhf.651681

Research Paper

Orjinal Makale / Orginal Paper

\title{
Eski Türklerde Güneş Algısı ve Atatürk’ün Güneș Olarak Sembolize Edilmesi
}

\author{
The Perception of Sun in Old Turks dnd Symbolization of Ataturk \\ as Sun
}

$\ddot{O} \mathbf{z}$

Güneş, insan varlı̆̆l üzerindeki ana fonksiyondur. Insanoğlu düşünmeye başlaması ile birlikte, evrendeki her şeyin üzerinde Güneşi tutmuş ve onun hayatın kaynağı olduğunu anlamıştır. Bu anlaylşla "Güneş” dini ve felsefi düşüncenin doğuşuna da etki etmiştir.

Tarih boyunca “Güneş”, kimi zaman gücünden korkularak tapınılan, tanrl yerine konulan, ulaşılmazlığın simgesi, varlık-yokluk gibi algllansa da, Türkler için farklı anlamlar da ifade etmiş ve Türk Kültürünün önemli bir öğesi olmuştur. Türkler Güneşe "Kün” yani bugünkü anlamıyla "gün” aydınlık olarak bakmışlardır. Saçtı̆̆g ışıklar, verdiği aydınlık, parlaklık, taşıdığ yükseklik, büyüklük, güç kudret, süreklilik gibi tüm fonksiyonları ile çok yönlü bir kavram olan "Güneş" resimde, şiirde, fotoğrafta, hatıralarda, köşe yazllarında, duygularda Atatürk ile bütünleştirilmiştir. Meşrutiyet yıllarından beri Atatürk’ün de söylediği "Gençlik Marşı’nda geçen “Güneş Şimdi Ufuktan Doğar” cümlesindeki "Güneş" Atatürk olmuştur.

Atatürk'ün kendisi de “Güneş” ile yakından ilgili olmuştur. Nitekim ünlü “Güneş Dil Teorisi” tam olarak bu konu ile bağlantılıdır. Dr. Hermann Kvergitsch'in yaptı̆̆ bir çalışmadan esinlenerek o dönem dil ile yapılan çalışmalardaki sorunlarl gidermek için "Güneş" in hayatın kaynaklı̆̆l gibi dilin de kaynağı olduğunu ve Türkçenin dünyada esas dil olduğunu kanıtlama yoluna gitmişti. Tam da bu çalışmaların yapıldığı sırada 1933 'te de Galatasaray kulübünden ayrılanların yeni kurdukları spor kulübüne "Güneş Spor Kulübü” adını da O önermiştir.

Bu çalışma, Atatürk’ün “Güneş Dil Teorisi” konusunu tartışma veya sadece onunla ilgili değildir. Çalışma çoğunlukla Atatürk'ün “Güneş” ile ifade edildiği söz, yazı, resim gibi öğeleri sunacaktır.

Anahtar Kelimeler, Atatürk, Güneş, Türk Kültürü, resim, fotoğraf.

\section{Abstract}

The sun is the main function on the human existence. As the man started to think, they valued the sun than anything and understood that it was the source of life. With this understanding, the "Sun" influenced the birth of religious and philosophical thought.

Although the "Sun" was perceived as a sign, symbol of existence-nonexistence, worshipped with fear, put in the place of the God, it was different for the Turkish public and became an important element of Turkish culture. Turks perceived the sun as the "day". The "Sun" which is a sophisticated concept along with its functions such as light,

ATIF: BOLAT Bengül, "Eski Türklerde Günes Alg1S1 ve Atatürk'ün Güneş Olarak Sembolize

Edilmesi" Tarih ve Gelecek Dergisi, 5/3 (Aral1k-2019), s. (609-623)

CITE: BOLAT Bengül, "The Perception of Sun in Old Turks dnd Symbolization of Ataturk as Sun"

Journal of History and Future, 5/3 (December- 2019), pp. (609-623) 
shine, greatness, power and continuity is integrated with Atatürk in paintings, poems, photos, maps, columns and emotions. The "Sun" in the phrase of "The Sun is rising from the horizon now" in the Youth Anthem which Atatürk had been signing since the Constitutional Period is Atatürk.

Atatürk is quite interested in the "Sun". Indeed, "Sun Language Theory" is fully linked to this issue. Inspired from a study carried out by Dr. Hermann Kvergitsch, he tried to prove that the "Sun" was the source of language as the source of life in order to remove the problems in the studies conducted for the language and that Turkish was the main language in the world. He proposed the name of "Güneş Spor Kulübü" (Sun Sports Club) for the club which was established by those left from Galatasaray in 1933 when these studies were carried out.

This study is not about discussion about Atatürk's "Sun Language Theory" or only about him. This will mostly present elements such as statements, writings and paintings in which Atatürk is expressed with the "Sun".

Key Words: Atatürk, Sun, Turkish Culture, Painting, Photography,

\section{Türklerde "Güneş"}

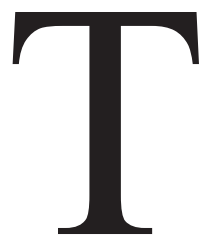

ürkler, İslamiyet'ten önceki tarihlerinde, Yahudilik, Budizm, Zerdüştlük, Manihaizm, Hıristiyanlık gibi dinler ile tanışmışlar, zaman zaman gruplar halinde bu dinlere geçmişlerse de genel olarak "Gök Tanrı" inancını devam ettirmişlerdir. Gök Tanrı’yı göğün ruhu şeklinde telakki ederken, Güneş, Ay, Yıldız, gibi gök cisimleri ile gök gürültüsü, şimşek gibi olayları kutsal ve semavi ruh şekilleri olarak tasvir etmişlerdir. Türkler, Güneş ve Ay’ı hiçbir zaman Tanrı olarak nitelendirmemekle birlikte, bu gök cisimlerinin kötülüklerle mücadele etmesi, karanlığı dağıtan 1şı̆̆1, bereket ve huzur getirmesi gibi özelliklerinden dolayı kutsal kabul etmişlerdir. Geleneksel Türk Dininde Güneş, Gök Tanrı inancının parçası olmuştur. İnsanın ölümlü olmasına karşın Güneşin sonsuz olması ve 1şı̆̆ını da Tanrı'dan aldığı inancı yaygın olmuştur. ${ }^{1}$

Hunlar, Güneşi “gün” anlamına gelen "kün” olarak nitelendirmişlerdir. Çin kaynaklarına göre, günün yani Güneşin kutsanması Hunlar dönemine kadar gitmektedir. Hun kağanlarının Güneşe olan saygılarından dolayı, otağlarının giriş kapılarını Doğu’ya yani Güneşin doğduğu yöne göre yaptıkları anlaşılmaktadır. ${ }^{2}$ Kaynakların verdiği bilgilere göre, Güneş ve Ay gibi gök cisimleriyle ilgili inanışlar Hunlardan sonraki Türk devletlerinde de devam etmiştir. Hatta bazı kahramanların Güneş ve Ay’ın lütfuyla Dünyaya geldiğine inanmışlardır. Modern Şaman davullarının çoğunda, Güneş, Ay ve yıldızların bulunması bu kültü işaret etmektedir. Yine kaynaklardan elde edilen bilgiler 1şı̆̆ında bu inanış ve sembollerin Anadolu Türk devletlerinde de devam ettiği görülmektedir. ${ }^{3}$

Altay Türklerinin inancına göre, Tanrı, Ay ve Güneşi gökyüzüne sonradan iki ayna gibi Dünyayı aydınlatmak için koymuştur. ${ }^{4}$ Güneş’i ve Ay’1 gök kubbenin fenerleri olarak kabul eden Gagauz Türkleri, Güneş’i annesi ve babası olan bir varlık olarak görmüşler ve Güneşin de Dünya kadar büyük olduğunu, ancak çok uzakta olduğu için küçük göründüğüne inanmışlardır. ${ }^{5}$

Türklerde kötülüklerle savaşıp, huzur ve bereketi getiren Güneşe hürmet gösterilmesi ve Onun koruyucu olarak nitelendirilmesi Tanrı'nın ona verdiği olağanüstü niteliklerden kaynaklan-

1 Abdülkadir Kıyak, “İslamiyet’ten Önce Türklerde Güneş ve Ay İle İlgili İnanışlar”, Karadeniz Sosyal Bilimler Dergisi, Say1.6, 4/2010, s.134.

2 Yaşar Kalafat, Doğu Anadolu'da Eski Türk İnancının İzleri, Atatürk Kültür, Dil ve Tarih Yüksek Kurumu Yay. Ankara, 1995, s.37.

3 Günay Üner\&Harun Güngör, Türklerin Dini Tarihi, Rağbet Yay, İstanbul, 2007, s.71.

4 Kiyak, a.g.m, s.139.

5 Harun Güngör\&Mustafa Argunşah, Gagauz Türkleri, Kültür Bakanlığı Yay., Ankara, 1991, s.42-45. 
dığına inanılmaktaydı. ${ }^{6}$ Türkler Tanrı tarafından bahşedildiğini düşündükleri Kağanlarını Güneş ile özdeşleştirmişlerdir. Koruyuculukta kağanlarına Güneş gibi oldukları yaklaşımı ile hürmet etmişlerdir. Kağan da Güneş gibi koruyucu, kötülüklerle mücadele eden, bereketi sağlayan, huzur getiren olarak görülmüş ve Güneş ile bütünleştirilmiştir. ${ }^{7}$

Hunlar'da, hakanın bazen gök veya yer, bazen de Güneş veya Ay tarafından atandığına inanılırdı. Örneğin bir yazıtta, "gök ve yer tarafından atanmış, Güneş ve Ay'dan doğma büyük Hun Şanyüsü” ifadesi bu inanışa örnek teşkil etmektedir. ${ }^{8}$ Geleneksel Türk Kültüründe Hakanlar, Güneşin oğulları olarak ve kendilerinin kuvvet kaynağının da Güneş olduğu ifade edilmiştir.9

Türklere göre; Güneş ile Ay bazen kötü ruhlarla mücadele ederler, eğer bu mücadeleyi kaybederlerse Güneş ve Ay tutulması meydana gelir. O yüzden de Altay Türkleri bu tutulmalarda bağırarak, davul, teneke çalarak kötü ruhları kovmaya çalışırlardı. Sahalara göre, Güneş ve Ay iki kardeştir, her ikisi de üstün özelliklere sahiptirler. Ancak Türkler Güneş ve Ay’ı hiçbir zaman Tanrı olarak kabul etmemiş ve tapmamışlardır. Onlara göre, doğada üstün varlıklardır ve güçlerinden dolayı bazen korku duymakla beraber büyük bir saygı beslemişlerdir. İnanç olarak Türkler gögü bir bütün olarak sembolleştirmiş ve Gök Tanrı inancını geliştirmişlerdir. Yani Gök Tanrı tüm varlıkların üstündedir. Kök Türkler ülkesinde, Kök Tengri’nin tek yaratıcı varlık olduğuna, Türklerin ateş, su, Güneş gibi bazı şeyleri kutsal saymalarına rağmen, ancak yer ve gögün yaratıcısı Gök Tanrı'ya taptıkları bilinmektedir. ${ }^{10}$

\section{Türk Tarihinin Öğrenilmesi ve Atatürk’ün Güneş Olarak Nitelendirilmesi}

Türklerin Anadolu'ya gelmeden önceki en eski tarihlerindeki siyasal, sosyal, ekonomik ve geleneksel yaşam biçimleri ile ilgili ciddi çalışmaların yapılması Cumhuriyet dönemine denk gelmektedir. Türkiye'de tarih alanında Cumhuriyet dönemine kadar olan kısmı özetlenecek olursa;

Osmanlı Devleti'nde Batılılaşma sürecine kadar olan devrede tarih çalışmaları genel olarak İslam tarihi üzerine oturtulmaya çalışılmıştır. Şöyle ki Klasik Dönem olarak da adlandırılan bu devrede, Türk tarihinden uzak bir şekilde İslam Tarihi ve Osmanlı Tarihi olarak kurgulanmış ve Osmanlı hanedanlığını kökenleri Peygamber soyu ile bütünleştirilmeye çalışılmıştır. ${ }^{11}$ Batı dünyasında başlayan milliyetçilik akımları XIX. Yüzyıldan itibaren Osmanlı Devleti'ne de sirayet etmiş ve Osmanlı Devleti'nin içinde bulunduğu sorunları, Batılılaşma yönünde yapılan Islahatlar ile giderme dönemi başlamıştır. Bu süreçte, tüm Osmanlı tebaasını bir arada tutabilmek için yoğun olarak yapılan Osmanlı milliyetçiliği çerçevesinde, Tanzimat ve Meşrutiyet dönemlerinde tarih alanındaki çalışmalar da daha bilimsel metotlar ile yapılmaya çalışılmıştır. ${ }^{12} \mathrm{Bu}$ dönem tarihçileri Tarih çalışmalarını, olayların nedenleri ve sonuçları ile birlikte geleneksellikten çıkarak pragmatik yöntemlerle yapmaya başlamışlardır. ${ }^{13}$ Tarih alanında okullarda İslam tarihinin yanı sıra Türk

6 Kıyak, a.g.m, s.137.

7 Kalafat, a.g.e, s.37.

8 Sencer Divitçioğlu, Orta- Asya Türk İmparatorluğu, İmge Kit. Ankara, 2005, s.115; Kıyak, a.g.m, s.141.

9 Murat Uraz, Türk Mitolojisi, Mitologya Yay., İstanbul, 1992, s.28.

10 Sadettin Gömeç, "Eski Türk İnancı Üzerine Bir Özet”, Ankara Üniversitesi Dil ve Tarih-Coğrafya Fakültesi Tarih Bölümü Tarih Araştırmaları Dergisi, Say1 33, Cilt 21, 2003, s.100-101.

11 Turhan Feyzioğlu, Atatürk ve Tarihl, Atatürk Haftası Armağanı, Ank. 1986, s.6.

12 Havva Akdağ, Tek Parti ve Demokrat Parti Dönemi Lise Tarih Ders Kitaplarının Muhtevası, Yüksek

Lisans Tezi, Konya, 2005, s.6.

13 Yahya Akyüz, Türk Eğitim Tarihi (1993’e kadar), İstanbul, 1994, s.229-235; Betül Başaran Alpugan, Geç Dönem Osmanlı İmparatorluğu’nda Tarih Yazıcılığı ve Tarih Kitapları, Osmanlı, C.8, Ankara, 
Tarihi ile de ilgili konulara da yer verilmeye çalışılmış, ancak bu çabalar Osmanlı Hanedanlığının tarihi olmaktan daha öteye gidememiştir. Dönem tarihçileri Osmanlı'nın beylikten imparatorluğa gidişinin ötesinde Türk Tarihine değinmemişlerdir. ${ }^{14}$ Tanzimat Dönemi yazılmış olan Tarih kitaplarında; Osmanlı Devleti'nin kuruluşu öncesi olaylar ve çoğunlukla Osmanlı Sultanlarının doğum, ölüm, cülus törenleri gibi konular ön planda tutulmuştur. Dolayısıyla Türklerin kendi tarihlerindeki inançları, törenleri ve geleneksel yaşamları ile ilgili bilgiler öğrenilememiştir. ${ }^{15}$

Osmanlı milliyetçiliğinin iflas ettiği ve Türkçülük’ün ön plana çıktığı II. Meşrutiyet Döneminde ise Türklerin Ata vatanları Orta Asya dönemi ile ilgili ilk bilgiler verilmeye başlamıştır. Tarih sadece siyasi tarih olarak değil kültürel yönleri de ele alınarak verilmeye çalışılmıştır. $\mathrm{Bu}$ dönem tarihçileri milli tarihi önemsemiş ve genel olarak Türk tarihini aydınlatma çabası içine girmişlerdir. ${ }^{16}$

II. Meşrutiyet dönemi içinde tarih alanında kurumsallaşmaya yönelik, Tarihi Osmani Encümeni Derneği kurulmuş Abdurrahman Şerif, Ahmet Tevfik, Ahmet Refik gibi tarihçiler aracılığı ile Tarih alanında çalışmalar yapılmıştır. Ayrıca Türk Ocağı kurulmuş ve Türk Yurdu, Genç Kalemler gibi dergiler aracılığı ile Orta Asya'daki Türk Tarihi ile ilgili yazılar yayınlanmaya başlamıştır. ${ }^{17}$

II. Meşrutiyet Dönemini Türk modernleşme süreci içinde oldukça önemli bir dönemdir. Bu dönemde özellikle Türk milliyetçiliğine yönelik önemli adımlar atılmış olmakla birlikte, aynı zamanda da siyasi bakımdan Osmanlı Devleti'nin en felaketli dönemi olmuştur. Devlet uzun zamandan beri üst üste kaybettiği savaşlar ile ağır bir toprak ve ekonomik kayıplar yaşamış, bunun yanı sıra milliyetçilik akımları ile tebaasını da büyük ölçüde kaybetmiştir. 1912-1913 yıllarındaki Balkan Savaşları ve sonrasında dört yıl süren I. Dünya Savaşı sonucunda artık devlet çökmüş ve yıkılmıştır. Tüm bu gelişmeler tüm alanlarda olduğu gibi tarih alanındaki çalışmaların da yarım kalmasına sebep olmuştur. Bu bağlamda Mondros Mütarekesi ve Sevr Anlaşmaları ile bir taraftan Osmanlı Devleti sona erdirilmeye çalışılırken, diğer taraftan da Türklerin Anadolu'daki varlıkları da ortadan kaldırılmak istenmiştir. Bu arada dönemin iktidarı İttihat- Terakki Partisi'nin Türkçü liderlerinin ülkeden çıkmaları ile siyasi anlamda Meşrutiyet dönemi de sona ermiştir.

$\mathrm{Bu}$ felaketli süreçte, Mustafa Kemal Atatürk liderliğinde yürütülen dört y1llık Milli Mücadele'nin sonunda 1923'te imzalanan Lozan Barış Anlaşması ile Anadolu'nun Türklere ait olduğu tüm büyük devletler tarafından kabul edilmiş ve bugünkü Türkiye Cumhuriyeti kurulmuştur.

Cumhuriyet ilan edildikten sonra, Atatürk dönemi olarak adlandırılan devrim sürecinde Onun tüm alanlardaki devrim hareketinde olduğu gibi Kültür alanındaki çalışmalarının temelini de millilik oluşturmuştur. Milliliğin esasını da toplumun sahip olduğu kültür değerleri oluşturmaktadır. Bu bağlamda Türkiye Cumhuriyeti'nin gelecek nesillerinin milli bir şuurla yetişmesini hedefleyen Atatürk, tarih konularına büyük önem vermiş ve kendi dönemi içinde özellikle Türk tarihi araştırmalarına öncelik vermiştir. ${ }^{18}$

1999, s. 265-267; Zeki Arıkan, Tanzimat'tan Cumhuriyete Tarihçilik, Tanzimat'tan Cumhuriyete Türkiye Ansiklopedisi, C.5, s.1586-1594.

14 Suna Kili, Türk Devrim Tarihi, İstanbul, 2005, s.312.

15 A.Fuat Baymur, Tarih Öğretimi, Ankara 1964, s. 13-14.

16 Bengül Salman Bolat, "Tanzimattan Demokrat Partiye Kültür Politikaları ve Tarih Anlayışları”, The Journal of Academic Social Science Studies ( JASS), Volume 5 Issue 8 , December 2012, s. 234-235.

17 Zeki Arıkan, Osmanlı Tarih Anlayışının Evrimill, Tarih ve Sosyoloji Semineri, (28-29 Mayıs 1990), İstanbul, 1991, s.77-91.

18 Sulhi Dönmezer, Milli Kültür, Ankara, 1983, s.21. 
1931 yılında Türk Tarih Kurumu'nun kurulması ile tarih araştırmalarında, dönemin modern teknikleri kullanılarak çok daha bilimsel ve geniş boyutlu araştırmalar yapmak hedeflenmiştir. Bir taraftan Atatürk'ün kendi "millilik" esası ile devrim hareketlerini yapması, diğer taraftan da 1920'li yılların sonundan itibaren, dünyada da gittikçe yükselen Milliyetçilik anlayışının da etkisiyle Türk Tarih Kurumunun, Türk milli tarihi araştırmalarına ağırlık verdiği görülmektedir. Dolayısıyla Cumhuriyetin ilk yıllarında, Türklerin en eski tarihlerinin araştırılması ve okullarda işlenen derslerde bu kısmın ağırlıklı olarak çok önemsendiği görülmektedir. ${ }^{19}$

$\mathrm{Bu}$ çalışmaların ilerlemesine bağlı olarak yıllar geçtikçe Türklerin en eski tarihlerindeki davranışarı, inanışları ve hareketleri günlük hayatın içersine girmiştir. Bu doğrultuda, Türklerin geçmişten itibaren "Güneş" ile ilgili inanışlarının da kullanılmaya başlandığ1 yorumu yapılabilir. Atatürk'ün Milli Mücadeleye önderlik yapması ile birlikte başlayan liderlik vasfı, Cumhuriyetin ilan edilmesi sonrasında Cumhurbaşkanlığı ile devam etmiştir. Bu sürecin içinde kökten bir devrim hareketi başlamış, bu devrime bağlı olarak ülkedeki gelişme gün gün kendini göstermiştir. Karanlıktan, aydınlığa bir süreç olarak ifade edilen bu devir çok çeşitli semboller, uygulamalar ve etkinlikler ile halka benimsetilme yoluna gidilmiştir. Atatürk döneminin yazarları, siyasetçileri, şairleri, gazetecileri ve halkı yaptıkları konuşmalarda, verdikleri eserlerde O'nu Türk'ün karanlıklarını aydınlatan bir "Güneş" olarak ifade etmişler ve yıllar boyuncada bu bir alışkanlık halinde devam etmiştir.

Atatürk'ün kendisi de "Güneş" i önemli bir unsur olarak görmüştür. Nitekim Güneşin aydınlığını, yaşam kaynağı olmasını ve önemini konuşmalarına yansıttığı̈ örnekler mevcuttur. O özellikle, Milli Mücadeleyi, karanlık günleri aydınlatan “Güneş” olarak görmüştür.Bu doğrultuda yapmış olduğu konuşmalara bir örnek verilecek olursa;

26 Mart 1937'de Bursa'da gençlerin düzenledikleri bir programda yapmış olduğu konuşmada, Milli Mücadele ve sonuçlarının ülke üzerine doğmuş bir güneş olduğunu ifade etmiştir. Konuşmasında, 19 Mayıs 1919'da yola çıktığında elinde hiçbir maddi gücün olmadığını, ancak kendisinin ve milletin içinde olan manevi gücün bu başarıyı sağladığını söylemiştir. Özellikle kendi gençlik dönemlerinde söyledikleri "dă̆ başını duman almış, güneş ufuktan şimdi doğar" şeklinde sözleri olan marşı o günlerde çokça söylediklerini ve bu marşın o günler için çok önemli olduğunu aktarmıştır. "Ben Türk ufuklarından bir gün behemehâl bir güneş doğacă̆ına, o kadar emindim ki, bunu adeta gözlerimle görüyordum. O şarkıyı oturttum tekrar ettirmekten maksadım Türk'ün bu güneşi doğunca muvaffak olacağını anlatmaktı. Bu sebeptendir ki demin söylenen şarkı benim on sekiz senelik bir hatıramı tazeledi.... "20 Sözleri ile Güneş vurgusu yapmıştır.

Türk Tarih Kurumu'nun yapmış olduğu yoğun çalışmaların yanı sıra 1932 yılında kurulan Türk Dil Kurumu da milli dil oluşturma yönünde yoğun bir mesai ile çalışmalarını yürütmekteydi. Dönemin politikaları içinde alfabe değişikliği ve Latin alfabesinin öğretilmesi çabaları tüm hızıyla devam etmekteydi. Alfabe yanında üzerinde en fazla durulan konu, Türk Dilinin yabancı kelime-

19 Bengül Salman Bolat, Tanzimat tan Demokrat Partiye Kültür Politikaları ve Tarih Anlayışları, The Journal of Academic Social Science Studies (JASS), Volume 5 Issue 8, Strasbourg/FRANCE, December 2012, p. 235-239.

20 Turgut Gürer, Atatürk'ün Yaveri Cevat Abbas Gürer Cepheden Meclise Büyük Önder İle 24 Y1l, 5. Bask1, Gürer Yay, İstanbul, 2007, s.248-249, II. Meşrutiyet Döneminde kutlanan bayramlardan birisi de İdman Bayramı olmuştur. Bu bayram ilk defa 1916'da yapılmıştır. Selim Sırrı (Tarcan) Bey, bu bayramdaki coşkuyu arttırmak amacıyla bir marş bulma yoluna gitmiş ve İsveçli Felix Karling bestesi olan “Şakıyan Üç Genç Kız” halk şarkısı uyarlanarak Gençlik Marşı adıyla İdman Bayramında söylenmiştir. Bkz. Bengül Salman Bolat, Milli Bayram Olgusu ve Türkiye'de Yapılan Cumhuriyet Bayramı Kutlamaları ( 1923-1960), Atatürk Araştırma Merkezi, Ankara, 2012, s. 31. 
lerden arındırılıp, kendi öz yapısına kavuşturulması çabaları olmuştur. Bu bağlamda 1930'lu yıllar Türkçenin sadeleştirilmesi yönündeki sayısız çalışmalarla doludur. Bu çalışmaları yürütülmesi, planlanması ve sonuçları ile ilgili olarak zaman zaman Türk Dil Kurultayları düzenlenmiş ve ilerleyen yıllarda genel olarak kaynağını öz Türkçeden alan kelimeler ile yabancı kökenli kelimeler yer değiştirmeye başlamıştır. Ancak oldukça radikal bir arılaşma yaşayan dilde yeni sorunlar da oluşmaya başlamış ve tüm yabancı kelimelerin atılamaya çalışılması Türkçeyi zenginleştirmekten ziyade, halkın zorlandığı bir şekle doğru gitmeye başlamıştır. ${ }^{21} 1936$ yılında III. Dil Kurultayında bu soruna Güneş Dil Teorisi ile çözüm bulunmaya çalışılmıştır. Dr. PhilH. F. Kvergic'in Atatürk'e göndermiş olduğu "Türk Dilinin başka dillerle ilişkisi” konulu bir çalışması, Atatürk'ün dil konusunda yaşanan sıkıntıyı gidermek için kullanacağı "Güneş Dil Teorisi” ne zemin hazırlamıştır. Bu teoriye göre, Güneş ilk insanlar için her şeyin üzerinde yüce bir güçtür, dolayısıyla insanoğlu ilk olarak güneşe isim vermişler ve A ğ demişlerdir. Bu Türkçe bir söylemdir. Türk Tarih Tezi’ne paralel olarak Türk dili, taş ve maden çağında kültür kavramlarını göç yoluyla bütün dünyadaki dillere yayan çok eski ve çok büyük bir kültür dilidir denmiştir. Böylece bütün dillerin Türkçeden doğmuş olması gibi bir sonuç çıkartılarak, yeryüzünde kökü Türkçe olmayan bir kelime olamayacağı savından hareketle, dilde özdeşleşmeden kaynaklı sorunlar giderilmeye çalışılmıştır. Atatürk Güneş Dil teorisiyle aslında yine kendisinin başlattığı dil tasfiyeciliğine bir nevi çözüm üretmiştir. ${ }^{22}$

Atatürk'ün "Güneş" e dair yaklaşımı ile ilgili bir diğer örnek de "Ateş Güneş Spor" Kulübü'dür. 1930'lu yılların başında, Galatasaray Spor Kulübü içinde yaşanan bir takım anlaşmazlıklardan dolayı bir bölünme yaşanmış ve bu kulüpten ayrılan bir gurup tarafından 1933 yılında Ateş- Güneş Kulübü kurulmuştur. Bir süre sonra Atatürk’ün isteği ile kulübün ismi “Güneş” olarak değiştirilmiş, 1937-1938 dönemi İstanbul ligini şampiyon olarak tamamlamış, Ancak Atatürk’ün ölümünden kısa bir süre sonra kapatılmıştır. ${ }^{23}$

\section{Atatürk’ün “Güneş” Olarak İfade Edilmesi}

1930’lu yıllarda örneklerine özellikle sıkça rastladığımız “Güneş” Atatürk tarafından da önemsenen bir unsur olmuştur. Ancak Cumhuriyetin ilanı ve sonrasındaki yıllarda daha çok Atatürk’ün kendisinin “Güneş”olarak ifade edildiği görülmektedir. Genel olarak resimler, fotoğraflar, özellikle de milli bayram ve Atatürk'ü anma günlerinde O'nun ve Cumhuriyetin "Güneş” ile ifade edildiği çok sayıda görsel, şiir ve yazılarda mevcuttur. Atatürk ve Güneşin birlikte resmedilmesi ve yazılması geçen her yıl tekrarlanarak yaygınlaşmış ve uzun yıllar boyunca aktarılan bir hal almıştır. Bu bağlamda Cumhuriyetin ilk yıllarından başlayarak günümüze kadar olan birkaç örneğe bakılacak olursa;

Cumhuriyet'in ilanından bir y1l sonra, 29 Ekim günü Hakimiyet-i Milliye Gazetesi, Cumhuriyeti “Güneş”olarak ifade etmiş ve "Geçen sene Bugün doğan Güneş Türk Milletinin ilk Cumhuriyet Gününü selamlamıştı" ${ }^{24}$ cümlesini kullanmıştır.

Cumhuriyetin onuncu yılı kutlamaları, o günden bugüne etkisini devam ettirmiş ve bu yıl yapılan kutlama ve törenler uzun yıllar boyunca tekrar edilerek günümüze kadar ulaşmıştır. ${ }^{25}$ Özellikle bu yıl yapılan kutlamalar içinde "Atatürk ve Güneş" temasının gerek, yazılarda, gerekse de gör-

21 Dil Devrimi ile ilgili bkz.Tuğrul Şavkav, Dil Devrimi, Gelenek Yay, İstanbul 2002.

22 Gökhan Yavuz Demir, “Türk Tarih Tezi İle Türk Dil Tezinin Kavşağında Güneş-Dil Teorisi”,Uludağ Üniversitesi, Fen- Edebiyat Fakültesi, Sosyal Bilimler Dergisi, Yıl,11, Say1, 19, 2010/2, s.391-393.

23 Cem Atabeyoğlu. 1453-1991 Türk Spor Tarihi Ansiklopedisi, Fotospor Yayınları İstanbul, 1991), s. 127. Türk Futbol Tarihi, Cilt I, Türkiye Futbol Federasyonu Yayınları, İstanbul, s. 27.

24 Hâkimiyet-i Milliye, 29 Ekim 1924, s.1.

25 Bolat, a.g.e, s.91-163. 
sellerde bolca kullanıldığını görmekteyiz. Daha önce belirtildiği gibi 1930'lu yıllardaki dünyadaki milliyetçilik akımlarının yükselmesine bağlı olarak, Türkiyede de önem verilen tarih çalışmalarından da esinlenerek "Güneş”vurgusunun ön plana çıkması örnekleri de artmıştır. Cumhuriyetin onuncu yılı kutlamaları çerçevesinde basında yer alan yazılarda Türk Tarihine vurgu yapılırken, Güneş temasının kullanımı da dikkat çekmektedir. Cumhuriyet gazetesi'nde yer alan ".. Tanrı Dağlarından doğan Güneşin ışıkları gözleri kamaştırdı.... ${ }^{26}$ Cümlesi Türk milleti Güneş olarak nitelendirilirken, "sen büyük kahraman ve büyük halk çocuğu! Gene içinden geldiğin bu muzdarip halkın arasından canlanan bir tabiat üstünde doğan bir ilkbahar güneşi gibi yükseldin" 27 denerek bu sefer de Atatürk ile güneş özdeşleştirilmiştir. Yine aynı yıl Atatürk için yazılmış bir şiirde;

“ Cumhuriyet, yarattı̆̆ın şaheser

Feyzi, yurdumuzu on yıldir bezer

Büyük adın hep yükseklerde gezer

Parlltın, kör gözleri bile sezer,

Yardın karanlıkları baştan başa

Türkü yücelten Güneşs sensin yaşa "28 Atatürk Güneş olarak nitelendirilmiştir.

Cumhuriyetin 10. Y1ldönümünde Cumhuriyet Gazetesi, Atatürk'ü ülkenin üzerindeki "Güneş" olarak tam sayfa bir fotoğrafla yayınlanmıştır. ${ }^{29}$ Adana' da yaşayan bir firın işçisi ise duygularını dile getiren bir resim yapmış ve dükkanının penceresine asmıştır. Dönemin basını ise bu resmi gazetelerinde yayınlamışlardır. ${ }^{30}$ Resimde 1923 'ten, 1933 'e kadar olan 10 yıllık süreçteki değişim ve gelişim sembolize edilirken, kurt figürü ile Türk tarihine vurgu yapılırken, Atatürk'ün de Güneş olarak ifade edilmesi dikkat çekmektedir.

Özellikle 1930'lu yıllarda gerek gazeteler, gerek yazı ve görsellerde yukarıda verilen örnekler gibi çok sayıda Atatürk- Güneş eşleştirilmesi bulmak mümkündür. Atatürk'ün 10 Kasım 1938'de vefatı sonrasında, yaşanan üzüntünün dile getirilmesinde de Güneş kullanılmıştır. Ulus Gazetesi'nden Zeki Mesut Alsan “O, bir güneşti, battı; O, bir yıldızdı, uçtu.. O, bir şahika idi, bulutlar arasına karıştı; $O$, bir denizdi, suları dă̆ıldı; $O$, bir yanardağdı, söndü... O, öldü diyorlar.. Bu ne demek?.. O, benim damarlarımda, benim başımda, benim kalbimde, benim ruhumda, hep yakıyor, hep yaşlyacak Hayır $O$, benim için ölmedi.. Senin için de, kimse için de ölmedi.. O, bende olduğu gibi, sende de, herkeste de yaşıyor... "31

Ölümü sonrası Harbiye'de yapılan bir törende, Yedek Subay öğrencilerinden birisinin, “Atatürk, Türkün Atasl.. Türkün en büyüğü, Türkün büyük askeri dahisi, Türkün her şeyi... Damarlarımızda yaktı̆̆ın ateş! Bütün kuvvetile benliğimizde yanıyor ve bizi heran memleket $i$ çin daha kuvvetle düşündürüyor. Ne mutlu. Atatürk; millî varliğımızı yakıcı, akıcı, tarumar edici bir kuvvet, bir volkan olarak tutuşturan güneşti. ${ }^{32}$ Sözlerinde "Güneş" ifadesi bulunmaktadır. Hatay'da yayınlanmakta olan Yeni Gün gazetesi de Atatürk’ün ölümü sonrasında Onu “Güneş”

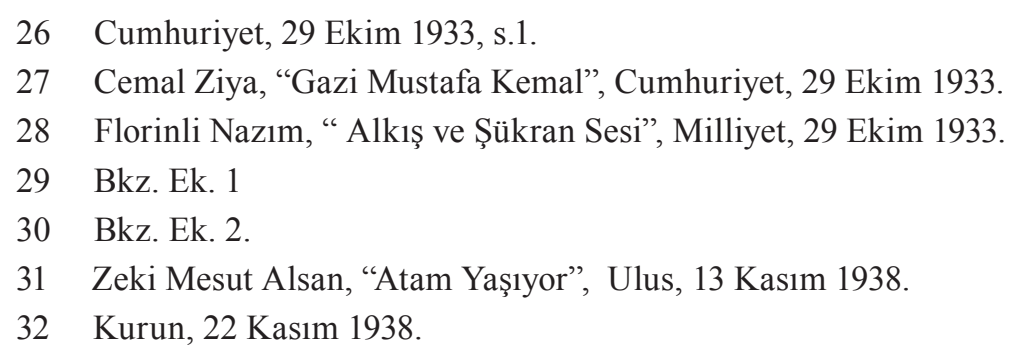


olarak nitelendirmiştir. ${ }^{33}$

Atatürk'ün Güneş ile birlikte ifade edilmesi, yoğun olarak 1930'lu yıllarda başlamıştır. Özellikle bu yıllarda gazete sütunlarında, şiirlerde ve benzeri görsellerde sıklıkla görülürken, zaman geçtikçe gerek onun hayata veda etmesi, şartların değişmesi ve siyasi bir takım gelişmelerden dolayı basın, kitap, köşe yazıları ve resmi kullanımlarda azaldığı tespit edilmiştir. Ancak Celal Bayar'ın, Atatürk'ten sonra ona olan duygularını ifade ederken sarf ettiği "Yüreğime eğiliyorum, acı taze; dün olmuş gibi. Yılları saylyorum, uzun bir zaman parçası; kırk bir yıl geçmiş. O gün doğanlar bugün milletvekili, mühendis, doktor, atom bilgini... Gençler görmediler onu... Sesini duymadılar. O ulu insana, büyük Devlet Adamı'na, eşsiz komutana değmediler... Ama hepsinin yüreğinde bir güneş var: ATATÜRK GÜNEŞİ “ (26.08.1979, Çiftehavuzlar) ${ }^{34}$ sözlerinden de anlaş1lacağı gibi Türk Milleti, aradan geçen zaman içinde Atatürk'ü Türk'ün güneşi olarak kabul etmeye devam etmiştir. Nitekim yapılan araştırma ve gözlemlerde, günümüzde de kadar yapılan afişlerde, okullardaki Atatürk köşelerinde ve milli bayram günlerinde kullanılan Atatürk fotoğraflarında yine “Güneş’in sıklıkla kullanıldığ1 görülmektedir”. ${ }^{35}$

Bu çalışmayı desteklemek ve bugünkü neslin Atatürk’e bakışını değerlendirmek amacıyla farklı bir uygulama yapılmıştır. Bu bağlamda Kırşehir ili içersinde biri özel kolej olmak üzere, iki okulda resim öğretmenleri ile görüşerek, 2018-2019 Eğitim öğretim y1lı boyunca, 29 Ekim Cumhuriyet Bayramı, 10 Kasım Atatürk'ü Anma ve 19 Mayıs Atatürk’ü Anma, Gençlik ve Spor Bayramlarında öğrencilerin bu haftalar için yaptıkları resim örnekleri üzerinden gidilmiştir. 5-8-11ve12.sinflardan alınan bu resimlerin büyük bir bölümünde Atatürk'ün "Güneş” ile ifade edildiği görülmüştür. ${ }^{36}$

\section{SONUÇ}

Atatürk'ün Samsun'a çıkışı ile başlayan Milli Mücadele dönemi, Anadolu'daki karanlık günlerin aydınlanmaya başlaması olmuştur. Nitekim Osmanlı Devleti'nin içinde bulunduğu şartlar, I. Dünya Savaşı sonrasında Anadolu insanının vatansız kalma ihtimalini oluşturmuştur. İşte bu ihtimalin ortadan kalkması ve 4 yıl süren Milli Mücadele ile mümkün olmuştur. Bu mücadele Atatürk önderliğinde onun dehası ile şekillenmiş ve adeta Anadolu'ya “Güneş" doğmuştur.Dünyada hiçbir lider Atatürk gibi Güneş olarak nitelendirilmemiştir demek herhalde abartılı olmayacaktır. Gerek Güneşin bilimsel anlamı, gerekse de inançlardaki anlamı Atatürk'ün şahsında toplanmış ve onunla birlikte ifade edilmiştir. Türkler, kendi tarihleri içinde zaman zaman kağanlarını koruyuculuklar1, güçleri ve yaptıkları ile özdeşleştirdikleri Güneş’i son olarak Atatürk ile bütünleştirmişlerdir. Öncelikle Milli Mücadeleden dolayı Anadolu üzerine doğan Güneş olarak ifade ederken, yaptı̆̆ devrim ile de 1şık saçan aydınlatıcı olarak yorumlamışlardır. Bu yorumlar Atatürk’ün kendi döneminde, siyasetçiler, yazarlar, şairler ve sanatçılar tarafından yapılırken, halk da bu akıma kapılmıştır. Ölümünden sonra da yine aynı gözle bakılmaya devam etmiştir. Bugün dahi Atatürk resimlerinde, afişlerinde, okullardaki Atatürk köşlerinde ve öğrencilerin yaptıkları resimlerde "Atatürk ve Güneş" bir arada yer almaya devam etmektedir.

33 Ulus, 18 Kasım 1938. Bkz. Ek 3.

34 İsmet Bozdağ, Bilinmeyen Atatürk, Celal Bayar Anlatıyor, Truva Yayınları, 2015.

35 Bkz. Ek.4

36 Bkz. Ek.5. 


\section{KAYNAKÇA}

\section{Kitap ve Makaleler}

Akdağ, Havva, Tek Parti ve Demokrat Parti Dönemi Lise Tarih Ders Kitaplarının Muhtevası, Yüksek Lisans Tezi, Konya, 2005.

Akyüz, Yahya, Türk Eğitim Tarihi (1993’e kadar), İstanbul, 1994.

Alpugan, Betül Başaran, Geç Dönem Osmanlı İmparatorluğu’nda Tarih Yazıcılı̆̆ı ve Tarih Kitapları, Osmanlı, C.8, Ankara, 1999.

Arıkan, Zeki, Osmanlı Tarih Anlayışının Evrimi, Tarih ve Sosyoloji Semineri, (28-29 Mayıs 1990), İstanbul, 1991.

Arıkan, Zeki, Tanzimat'tan Cumhuriyete Tarihçilik, Tanzimat'tan Cumhuriyete Türkiye Ansiklopedisi, C.5.

Atabeyoğlu. Cem, 1453-1991 Türk Spor Tarihi Ansiklopedisi, Fotospor Yayınları İstanbul, 1991.

Baymur, A.Fuat, Tarih Öğretimi, Ankara 1964.

Bolat, Bengül Salman, "Tanzimattan Demokrat Partiye Kültür Politikaları ve Tarih Anlayışları", The Journal of Academic Social Science Studies ( JASS), Volume 5 Issue 8 , December 2012.

Bolat, Bengül Salman, Milli Bayram Olgusu ve Türkiye'de Yapılan Cumhuriyet Bayramı Kutlamaları ( 1923-1960), Atatürk Araştırma Merkezi, Ankara, 2012.

Bozdağ, İsmet Bilinmeyen Atatürk, Celal Bayar Anlatıyor, Truva Yayınları, 2015.

Demir, Gökhan Yavuz, “Türk Tarih Tezi İle Türk Dil Tezinin Kavşağında Güneş-Dil Teorisi”,Uludağ Üniversitesi, Fen- Edebiyat Fakültesi, Sosyal Bilimler Dergisi, Y11,11, Sayı, 19, $2010 / 2$.

Divitçioğlu, Sencer, Orta- Asya Türk İmparatorluğu, İmge Kit. Ankara, 2005.

Dönmezer, Sulhi, Milli Kültür, Ankara, 1983.

Feyzioğlu, Turhan, Atatürk ve Tarih I, Atatürk Haftası Armağanı, Ank. 1986.

Gömeç, Sadettin, “Eski Türk İnancı Üzerine Bir Özet”, Ankara Üniversitesi Dil ve TarihCoğrafya Fakültesi Tarih Bölümü Tarih Araştırmaları Dergisi, Sayı 33, Cilt 21, 2003.

Güngör Harun \& Argunşah, Mustafa, Gagauz Türkleri, Kültür Bakanlığı Yay., Ankara, 1991.

Gürer, Turgut, Atatürk'ün Yaveri Cevat Abbas Gürer Cepheden Meclise Büyük Önder İle 24 Y11, 5. Bask1, Gürer Yay, İstanbul, 2007,

Kalafat, Yaşar, Doğu Anadolu'da Eski Türk İnancının İzleri, Atatürk Kültür, Dil ve Tarih Yüksek Kurumu Yay. Ankara, 1995.

Kıyak, Abdülkadir, "İslamiyet’ten Önce Türklerde Güneş ve Ay İle İlgili İnanışlar”, Karadeniz Sosyal Bilimler Dergisi, Sayı.6, 4/2010.

Kili, Suna, Türk Devrim Tarihi, İstanbul, 2005.

Şavkav Tuğrul, Dil Devrimi, Gelenek Yay, İstanbul 2002.

Türk Futbol Tarihi, Cilt I, Türkiye Futbol Federasyonu Yayınları, İstanbul. 
Uraz, Murat, Türk Mitolojisi, Mitologya Yay, İstanbul, 1992.

Üner Günay \& Güngör, Harun, Türklerin Dini Tarihi, Rağbet Yay, İstanbul, 2007.

\section{Gazeteler}

Alsan, Zeki Mesut, “Atam Yaşıyor”, Ulus, 13 Kasım 1938.

Cumhuriyet, 29 Ekim 1933.

Hâkimiyet-i Milliye, 29 Ekim 1924.

Kurun, 22 Kasim 1938.

Nazım, Florinli, “ Alkış ve Şükran Sesi”, Milliyet, 29 Ekim 1933.

Ulus, 18 Kasim 1938.

Ziya, Cemal, “Gazi Mustafa Kemal”, Cumhuriyet, 29 Ekim 1933.

\section{EKLER}

Ek. 1

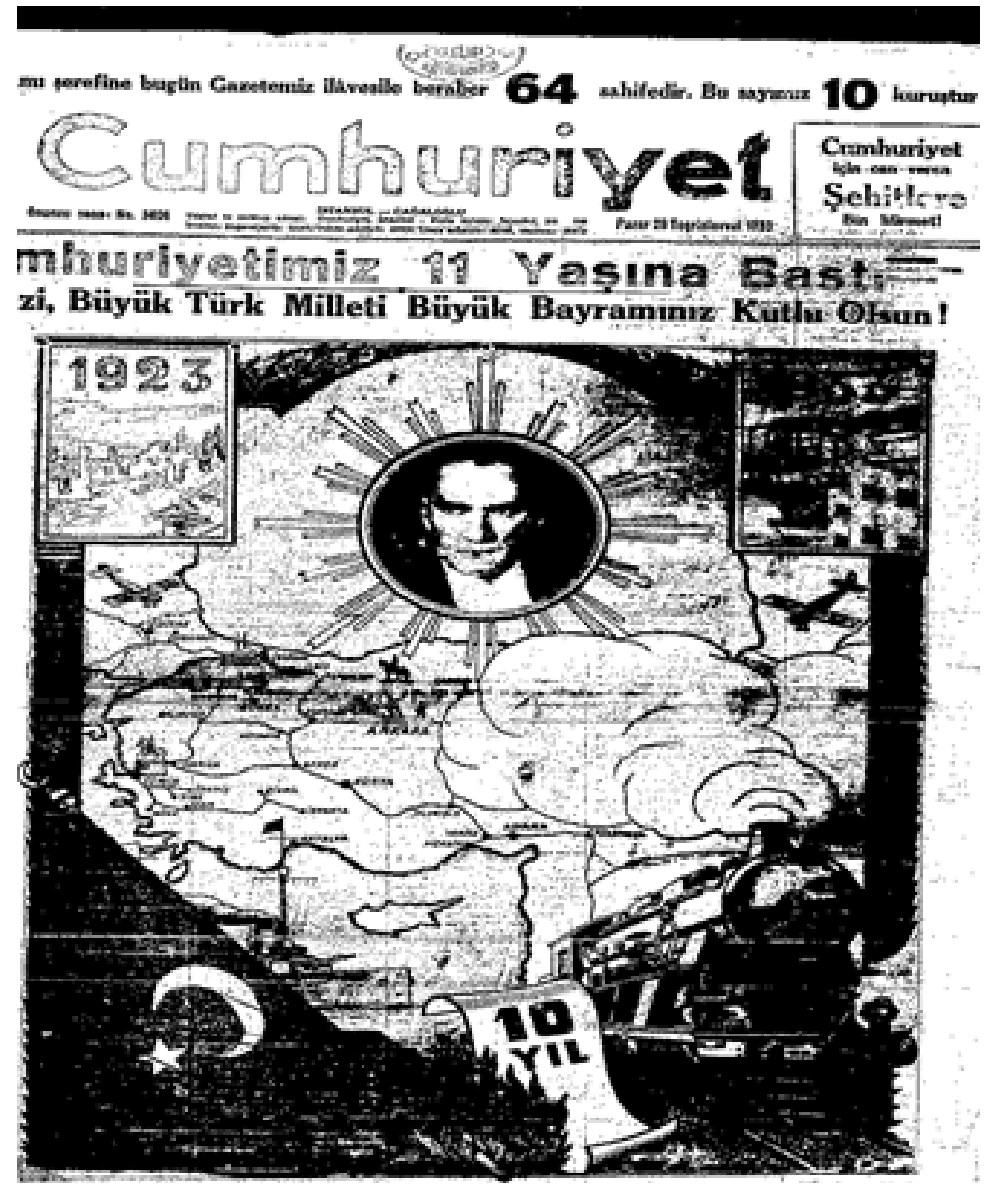


Ek. 2

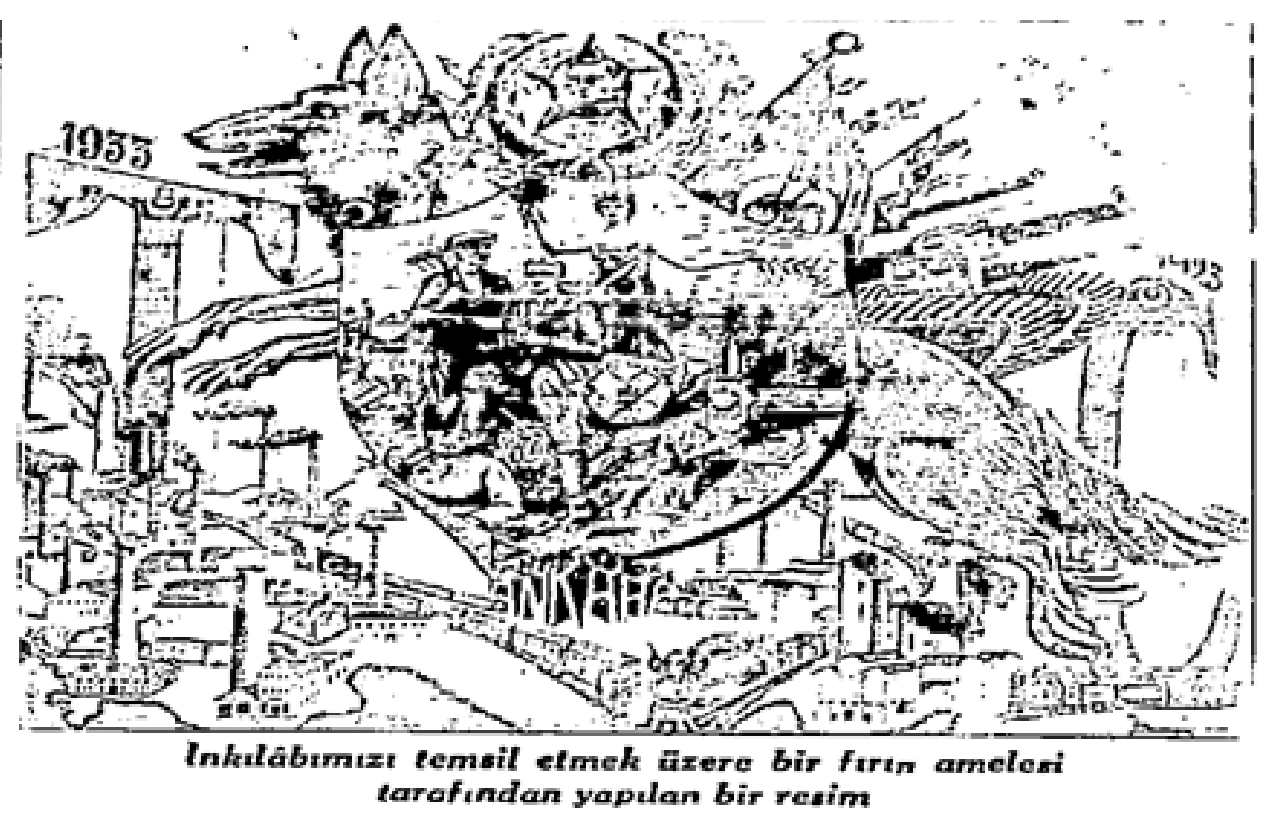

Ek.3

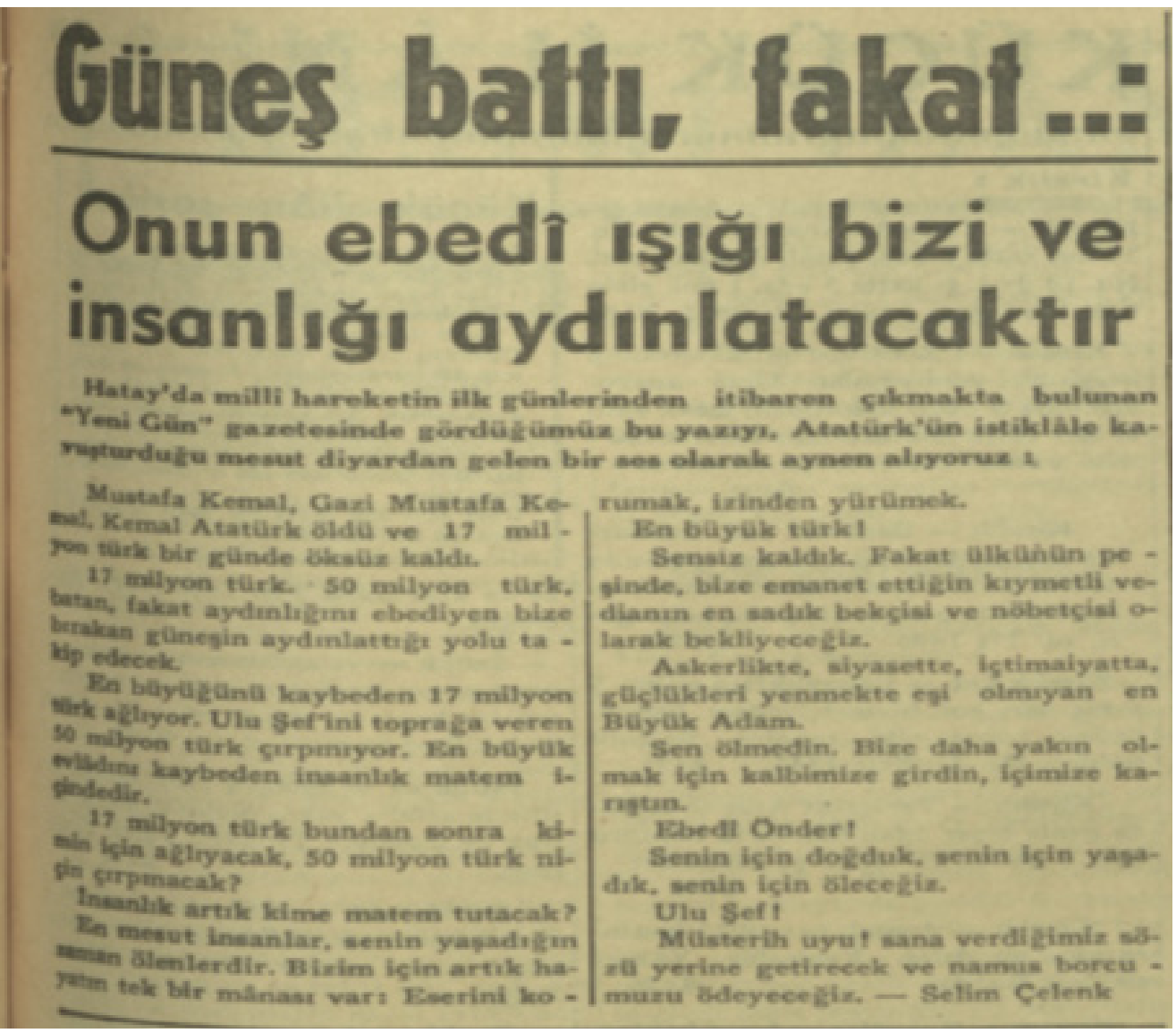


Ek.4
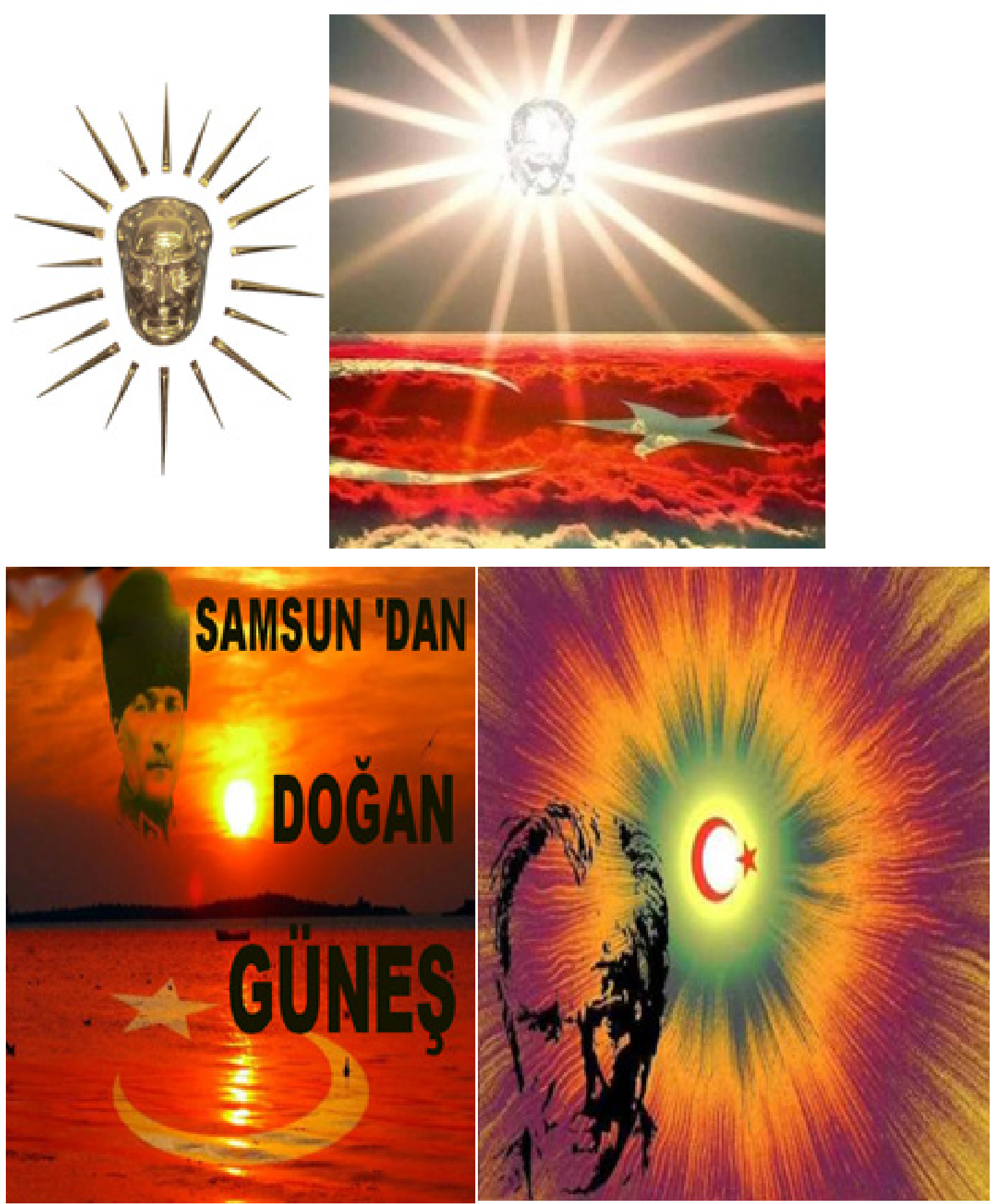
Ek. 5
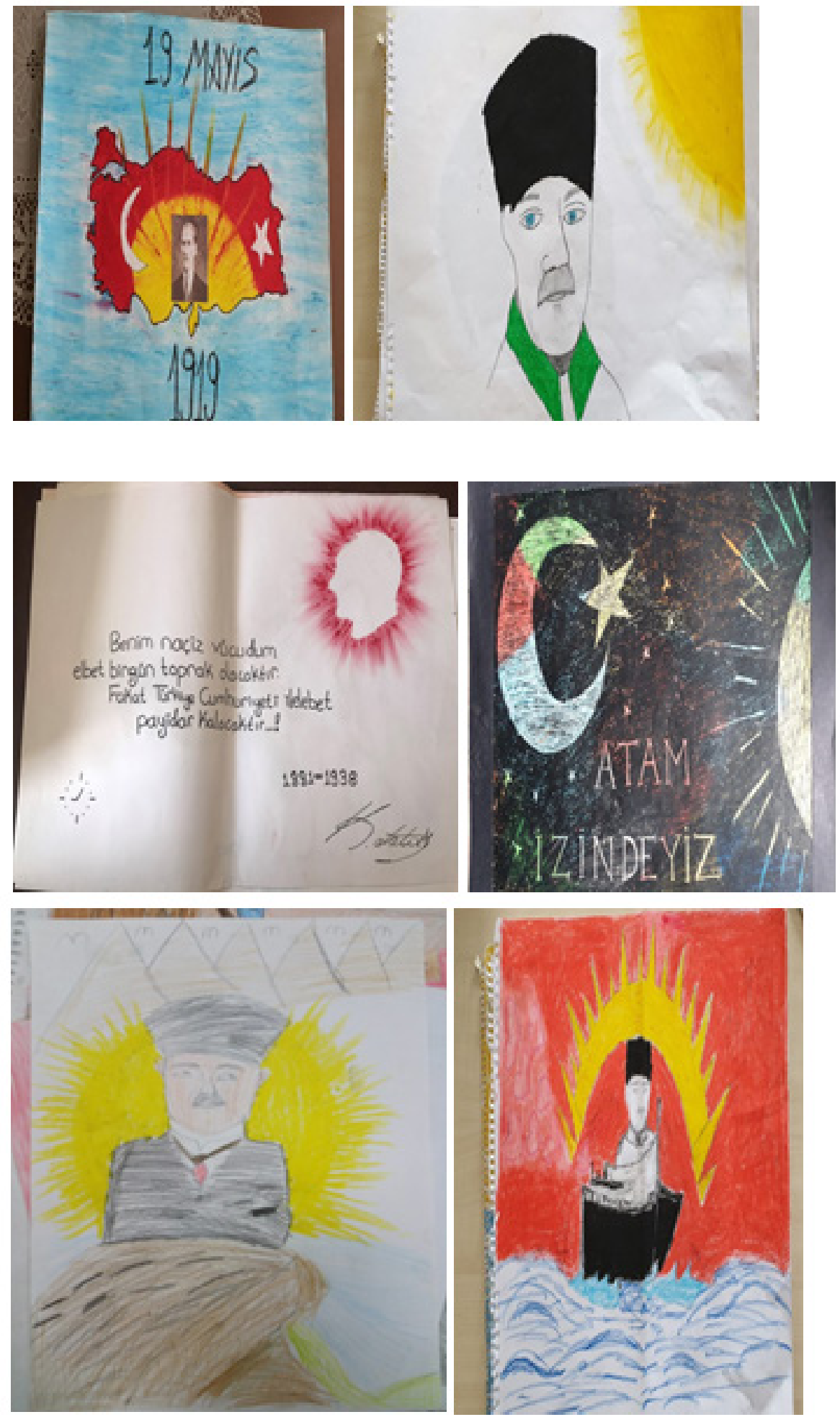

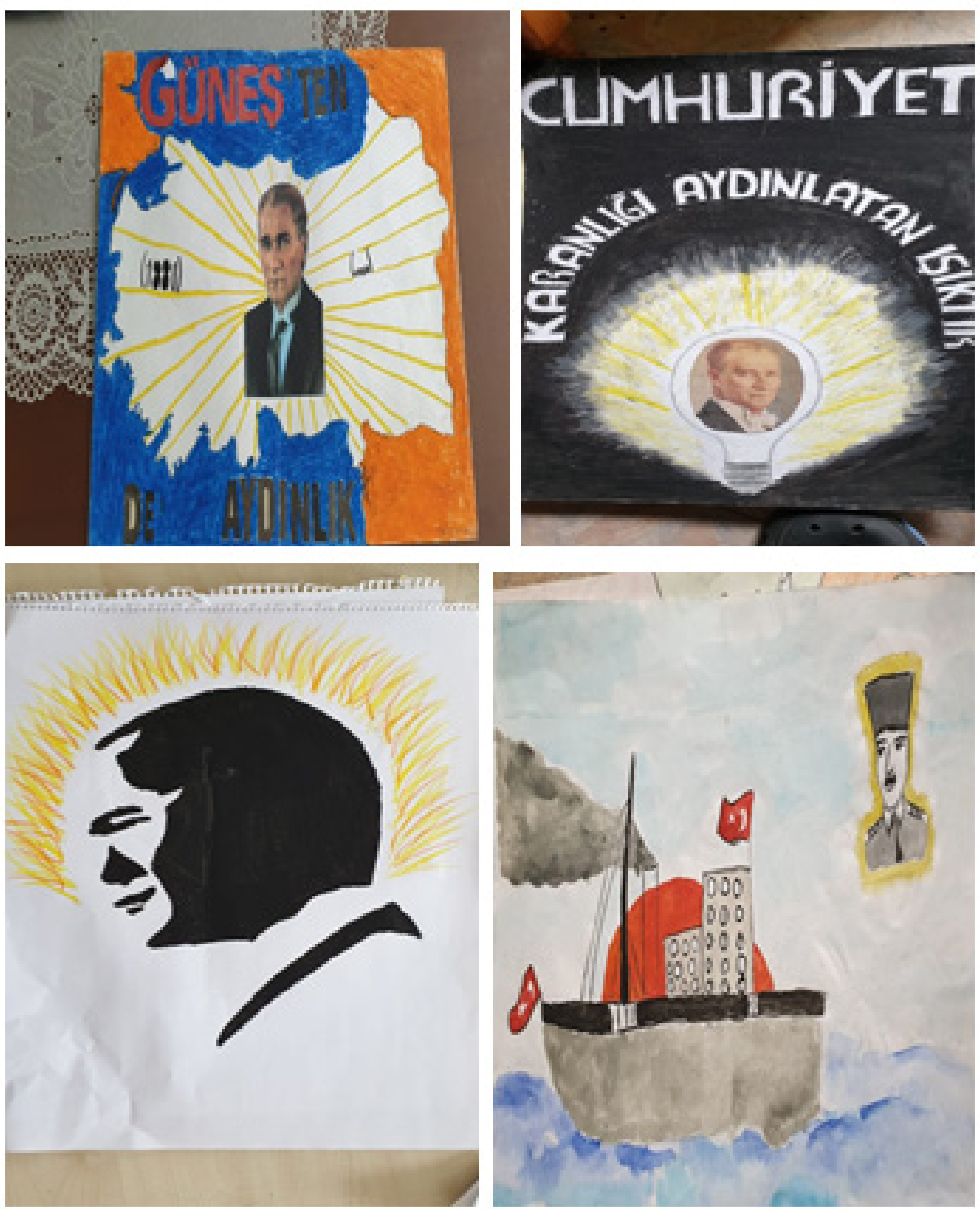

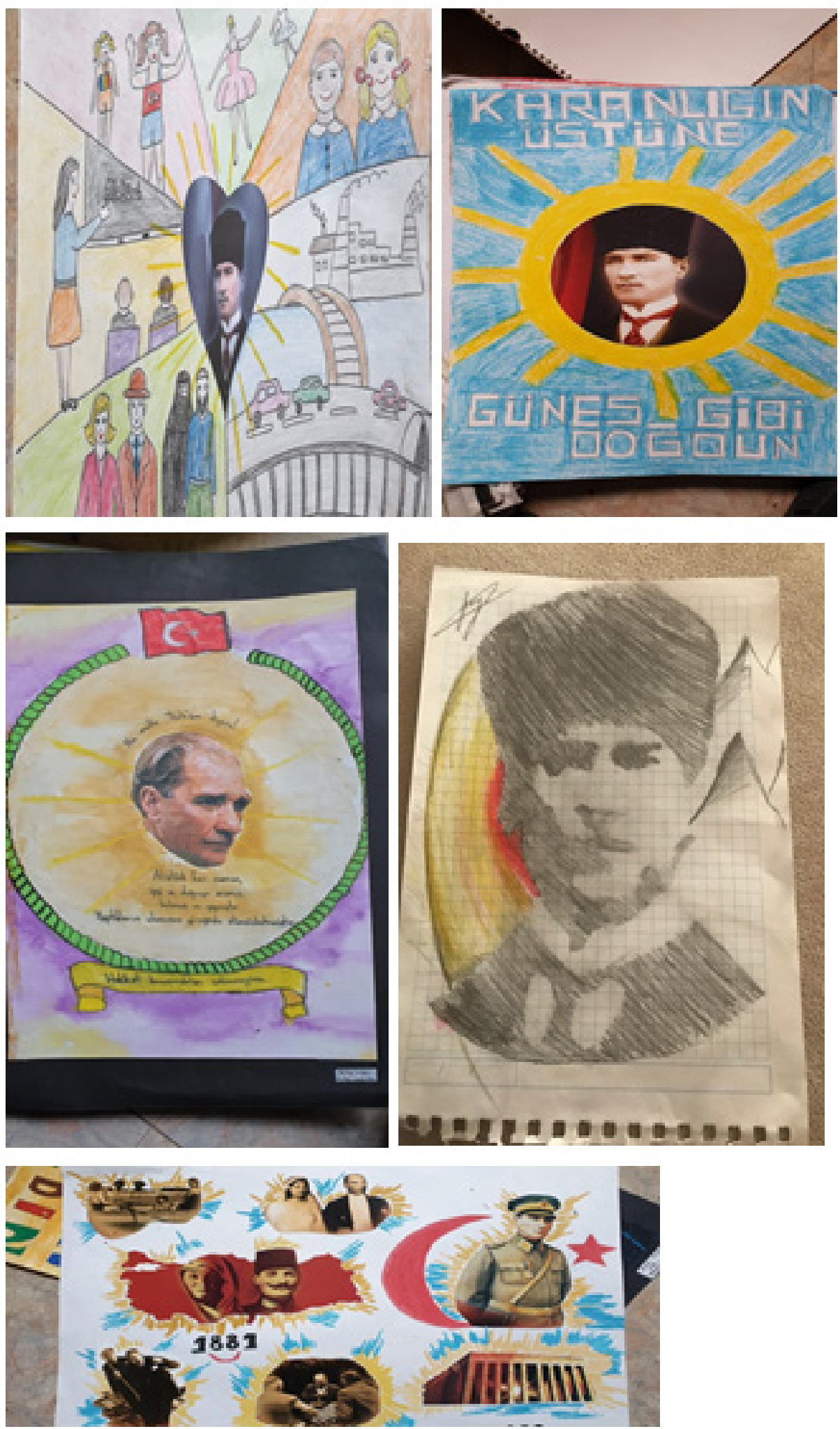